\title{
Luciente Domergue
}

\author{
Antonio Risco
}

En el momento de cerrar esta entrega de los Cuadernos nos llega la triste noticia de la brutal desaparición de Lucienne Domergue, catedrática emérita en la Universidad de Toulouse (Francia).

Lucienne Domergue estuvo vinculada desde el principio a la andadura del Instituto Feijoo y a todos sus proyectos, tanto en lo relativo a congresos y coloquios, como a la labor editorial. Últimamente preparaba para el Instituto la edición de las Obras Completas de León de Arroyal. La muerte la ha sorprendido sin permitirle terminar esta tarea, emprendida con el entusiasmo vital que todos conocíamos y que tan fácilmente comunicaba a quienes la rodeaban.

La catedrática de Toulouse, nacida en el bucólico departamento del Gers, en donde conservaría siempre unas sólidas raíces y una campestre morada, cursó sus estudios hispánicos en la misma Universidad donde más tarde enseñaría e inició su carrera, como joven catedrática de Instituto, en París, antes de pasar, ya como investigadora universitaria a la Casa de Velázquez de Madrid, cuya calidad de miembro ostentaba. De regreso a su universidad tolosana, en vísperas del 68, la mies madrileña produjo un inicial y ya estimulante fruto: su tesis doctoral sobre Jovellanos en la Sociedad Económica de los Amigos del País de Madrid (1778-1795), leída en 1969 y editada en 1971. La vocación dieciochista de Lucienne Domergue se desarrollará desde entonces sin desmayo y la obtención del «Doctorat d'Etat» (Habilitación de cátedras) en 1976, la convertirá en heredera y activa representante de una de las tradiciones del hispanismo tolosano, la dedicada, precisamente, a los estudios sobre el siglo xviII español, que antes ilustraran los nombres de Paul Mérimée y de Lucien Dupuis.

No evocaré aquí la totalidad de su producción científica —muy numerosas fueron sus colaboraciones en forma de artículo o de participación en obras colectivas-, y me limitaré a recordar tan sólo algunos hitos de lo que fue un largo camino de investigación y escritura. Las aportaciones de Lucienne Domergue resultan 
hoy fundamentales para la comprensión de ciertos elementos estructurantes de la Ilustración, y, singularmente, en el importante capítulo de la censura y la circulación de libros: Tres calas en la censura dieciochesca (1981), Censure et Lumières dans l'Espagne de Charles III (1982), Le livre en Espagne au temps de la Révolution Française (1984), La censure des livres en Espagne à la fin de l'Ancien Régime (1996), obra esta última que, junto con la más antigua de Marcelin Défourneaux, un maestro admirado por Lucienne, se ha convertido en referencia indispensable. Ulteriormente, la sagaz mirada de Lucienne Domergue pasó de las Luces a la luz y a las sombras del pintor Goya (Goya. Des délits et des peines, 2000), en cuyos claroscuros encontró la incitación necesaria para interesarse por la «otra cara» del Siglo de las Luces, la de las sombras y la marginalidad. Con emoción, me permito así evocar el libro que firmamos mano a mano en 2001: L'Alcade et le malandrin. Justice et société en Espagne au XVIII siècle, fruto de un apasionante diálogo compartido en Toulouse y en los seminarios de la Maison des Sciences de l'Homme, en París. No quiero dejar de mencionar, para cerrar esta sucinta evocación, la labor de Lucienne Domergue como organizadora y editora de encuentros científicos en Toulouse: los que llevaron a la publicación de dos obras colectivas: Après 89. La Révolution, modèle ou repoussoir? (1991) y Pueblo, Nación y Élites (1996).

A pesar del salto cronológico, no deja de haber cierta relación entre la mirada interesada y compasiva hacia los desafortunados que inspirara aquellas investigaciones y la que, paralelamente, llevó a Lucienne Domergue a interesarse por otro infortunio español: el que protagonizaron los exiliados republicanos de 1939. Bien es verdad que en Toulouse, capital meridional del exilio francés, había una realidad histórica y humana ante la que Lucienne Domergue no permaneció indiferente. Y así fue como Lucienne incorporó a su agenda de investigadora universitaria encuestas y publicaciones sobre el exilio tolosano, en las que lo científico y lo sentimental se dieron la mano. Con una atención particular al movimiento anarquista en la edición conjunta con Marie Laffranque de El castillo maldito (1992) y de los Cuentos de amor de Federico Urales (2003). Como si se tratase de una forma solidaria de compartir aquella desventura colectiva, la investigadora se sumergió en el trabajo de equipo: el que nos llevó a la elaboración conjunta con un grupo de la UNED en el que figuraban especialistas españoles reputados (Alicia Alted, Santos Juliá...) del documental Exils. Réfugiés espagnols dans le Midi de la France (1994) o el que, como editora, asumió con la publicación de L'exil républicain espagnol à Toulouse. 1939-1999 (1999), del que, en 2003, se hizo una versión española.

Quiero señalar, finalmente, la riqueza de una trayectoria de hispanista no anclada en las imágenes de aquel Madrid de los 60 que quien esto firma revivía con frecuencia a través de los recuerdos narrados con talento por la amiga y colega. También la España de hoy interesó, personal y profesionalmente, a Lucienne 
Domergue: desde su temprana pasión, a la que no debían ser ajenos los recuerdos de Marruecos, por la obra de Juan Goytisolo (De Sur a Sur, 1994) hasta la visión colectiva propuesta en Aujourd'hui l'Espagne (1995), publicaciones que impulsó como primera directora del «Centro de Investigaciones sobre la Península Ibérica en los siglos XVIII-XIX-XX» (CRIC) que, en compañía de Jacques Beyrie y de Yvan Lissorgues, imaginara Lucienne Domergue para dar cabida a las tareas de los hispanistas tolosanos dedicados al estudio de esas épocas. Lo que acredita que Lucienne no eludió tampoco las responsabilidades administrativas, y, como no podía ser menos en un cursus de más de un cuarto de siglo de docencia universitaria, también asumió, en su momento, la pesada carga de Directora del Departamento de Estudios Hispánicos e Hispanoamericanos de la Universidad de Toulouse.

Más allá de todo ello, nos queda, y, sobre todo, queda para las generaciones de dieciochistas más jóvenes o por venir, la escritura estimulante, siempre ágil y nerviosa, de Lucienne Domergue. Adiós, Lucienne. 